\title{
PENGEMBANGAN MODUL PEMBELAJARAN FISIKA BERBASIS PROBLEM BASED LEARNING (PBL) PADA MATERI GELOMBANG BUNYI UNTUK SISWA SMA KELAS XII
}

\author{
Tri Anita Nur Hasanah' ${ }^{1}$, Choirul Huda ${ }^{2)}$, Maris Kurniawati ${ }^{3)}$ \\ ${ }^{1,2,3)}$ Program Studi Pendidikan Fisika,Universitas Kanjuruhan Malang, Indonesia
}

\begin{abstract}
The 2013 curriculum emphasizes on Scientific Approach taht tie topic with real context. Either learning model that leads to Scientific Approach that is Problem Based Learning (PBL). So that need to prepare appropriate teaching material to support learning model PBL one of them module independent teaching topic for learners. The aim of these research is describe the Learning Module which is developed that is physic learning module based on PBL of the topic sound wave for senior high school grade XII and examine its feasibility. This development research used 4-D Thiagarajan with modified model. This research has been done in three stages such as define, design, and develop which are restricted until the limited tryout. The data collection is used questionnaire. The module validation by 4 validators and limited try out to 10 students. The result of research drawn that material aspect is 3,59 with the suitable criterion, presentation aspect is 3,9 with the suitable criterion, language aspect is 3,41 with the suitable criterion, and the limited try out result got 3,6 with an appropriate criterion. In conclusion, physic learning module based on PBL in sound wave material for senior high school grade XII is applicable.
\end{abstract}

Keywords: Physic Learning Module, Problem Based Learning (PBL), Topic sound wave

\begin{abstract}
Abstrak
Pada kurikulum 2013 menekankan pada Scientific Approach yang mengaitkan materi dengan konteks dunia nyata. Salah satu model pembelajaran yang mengarah ke Scientific Approach yaitu Problem Based Learning (PBL). Sehingga perlu dipersiapkan bahan ajar yang tepat untuk mendukung model pembelajaran PBL salah satunya modul yang merupakan bahan ajar mandiri bagi peserta didik. Tujuan penelitian ini adalah mendeskripsikan pengembangan modul yaitu modul pembelajaran fisika berbasis PBL pada materi Gelombang Bunyi untuk siswa SMA kelas XII dan menguji kelayakannya.Penelitian pengembangan menggunakan model 4-D Thiagarajan yang sudah di modifikasi. Penelitian ini dilakukan dalam tiga tahap yaitu pendefinisian (define), perancangan (design) dan pengembangan (develop) yang dibatasi sampa uji coba terbatas. Validasi modul oleh 4 validator dan uji coba terbatas kepada 10 orang siswa. Dari hasil penelitan diperoleh skor segi materi sebesar 3,59 dengan kriteria layak, segi penyajian sebesar 3,9 dengan kriteria layak, segi bahasa sebesar 3,41 dengan kriteria layak dan hasil uji coba terbatas mendapat rerata skor sebesar 3,6 dengan kriteria sesuai. Dapat disimpulkan bahwa modul pembelajaran fisika berbasis PBL pada materi Gelombang Bunyi untuk siswa SMA kelas XII layak digunakan.
\end{abstract}

Kata Kunci: Modul Pembelajaran Fisika, Problem Based Learning (PBL), Gelombang Bunyi

DOI : http:/dx.doi.org/10.21067/mpej.v1i1.1631

Diterima: Februari 2017; Disetujui: Maret 2017

\section{PENDAHULUAN}

Menurut Permendikbud No. 65 tahun 2013, kurikulum 2013 menekankan pada

* Corresponding Author:

trianita6162@gmail.com pendidikan karakter peserta didik yang dipandu dengan kaidah-kaidah pendekatan 
ilmiah dalam proses pembelajarannya. pemecahan masalah (Chiang \& Lee, 2016) Upaya penerapan Pendekatan ilmiah dan berpengaruh bagi pemahaman konsep (Scientific Approach) dalam proses serta keterampilan berfikir kritis peserta pembelajaran merupakan ciri khas dari didik (Kartika, 2014).

Kurikulum 2013. Scientific Approach

Model pembelajaran PBL juga dapat diyakini merupakan jembatan meningkatkan prestasi peserta didik dan perkembangan dan pengembangan sikap, keterampilan proses sains (Ukoh \& keterampilan, dan pengetahuan peserta Enyeneokpon, 2012). Jadi, model PBL didik. Model pembelajaran yang dipandang sangat cocok diterapan dalam sejalan dengan prinsi-prinsip pendekatan pembelajaran fisika mengingat scientific salah satunya Problem Based bahwasannya materi fisika berupa konsep, Learning (Mutia \& Serevina, 2014). Model hukum, prinsip, dan teori yang berkaitan PBL menuntun peserta didik untuk erat dengan lingkup permasalahan dalam mengenal masalah, merumuskan masalah, kehidupan sehari-hari. Maka dari itu perlu mencari solusi atau menguji jawaban dipersiapkan bahan ajar yang tepat untuk sementara atas suatu masalah/pertanyaan mendukung model pembelajaran PBL. dengan melakukan penyelidikan Bahan ajar adalah segala bentuk (menemukan fakta-fakta melalui bahan yang digunakan untuk membantu penginderaan), pada akhirnya dapat guru atau instruktur dalam melaksanakan menarik kesimpulan dan menyajikannya kegiatan belajar mengajar, salah satunya secara lisan maupun tulisan.

yaitu modul (Nugraha, 2013). Modul

Problem Based Learning (PBL) dikemas secara utuh, sitematis dan didesain merupakan pembelajaran kontekstual yang untuk membantu peserta didik menguasai mengkaitkan materi pembelajaran dengan tujuan belajar yang spesifik (Daryanto, konteks dunia nyata peserta didik 2013). Peserta didik memerlukan bantuan (Mulyasa, 2009). Sehingga peserta didik pendampingan kognitif dalam belajar fisika dapat belajar tentang cara berpikir kritis salah satunya adalah modul yang dapat dan keterampilan pemecahan masalah, digunakan belajar mandiri bagi peserta serta memperoleh pengetahuan dan konsep didik. Modul yang dikembangkan yang esensial dari materi pelajaran. Hal ini disesuaikan dengan kehidupan sehari-hari sesuai dengan penelitian yang menyatakan peserta didik. Bahan ajar dikatakan layak bahwa model pembelajaran PBL mampu menurut BSNP (Muslich, 2010 dan memfasilitasi peserta didik dalam proses Depdiknas, 2007) apabila memenuhi empat 
komponen yaitu kelayakan isi, kelayakan kebahasaan, kelayakan penyajian, dan kelayakan kegrafikan.

Berdasarkan analisis kebutuhan melalui angket di SMA Negeri 2 Malang diperoleh kesimpulan bawasannya peserta didik masih belum menggunakan modul pembelajaran yang disusun oleh guru bahkan tidak memiliki modul untuk belajar mandiri, peserta didik tidak dapat mengaitkan materi pembelajaran dengan kehidupan sehari-hari. Sehingga peserta didik membutuhkan modul sebagai alternatif belajar mandiri.

Hal ini sesuai dengan hasil penelitian yang menyatakan di SMA kota Malang dan SMA di Tulungagung menunjukkan $61 \%$ peserta didik mengandalkan buku paket, 71 $\%$ peserta didik menyatakan buku panduan belajar yang digunakan kurang menarik dan sulit dipahami. Hasil observasi di toko buku yang ada di Kota Malang dapat disimpulkan bahwa bahan ajar kurikulum 2013 mata pelajaran fisika masih sedikit dan kurang sesuai dengan kurikulum 2013.

Pada tahun 2015 dimalang diperoleh informasi bahwa penggunaan modul dalam pembelajaran fisika sangat diperlukan. Modul dapat membantu peserta didik untuk memahami konsep fisika dan menigkatkan keterampilan proses sains peserta didik. Sebanyak 76,7 \% peserta didik juga lebih memilih modul yang berisi rangkuman

materi, praktikum dan soal yang disertai pembahasan. Karakter bahan ajar yang dibutuhkan peserta didik tersebut merupakan sebuah modul (Wulandari, 2015).

Materi yang digunakan dalam penelitian ini adalah Gelombang Bunyi. Materi gelombang bunyi dipilih atas dasar hasil penyebaran angket yang menunjukkan $77,7 \%$ peserta didik menyatakan bahwa materi gelombang bunyi merupakan materi yang sulit dipelajari. Gelombang bunyi adalah materi yang sulit dimengerti karena banyak kesalahan konsep dalam memahami persamaannya (Wittmann, 2003). Miskonsepsi juga terjadi pada saat peserta didik memahami konsep perambatan bunyi melalui medium hingga sampai ke telinga pendengar (Sadgolu, 2013). Ditambah lagi materi gelombang bunyi juga terlalu banyak persamaan sehingga memperbesar peluang terjadinya miskonsepsi (Sulistyarini, 2015).

Pengembangan modul pada penelitian ini menggunakan Model 4D (define, design, development and dissemination) yang dimodifikasi sampai tahap develop pada uji coba terbatas. Kelebihan model 4D adalah lebih tepat digunakan sebagai dasar untuk mengembangkan perangkat pembelajaran 
bukan untuk mengembangkan sistem Pada tahap develop dilakukan validasi pembelajaran (Arywiantari dkk., 2015). kepada ahli materi, media dan guru fisika.

Berdasarkan latar belakang di atas, Setelah hasil validasi dilakukan revisi maka dilakukan penelitian pengembangan berdasarkan hasil saran oleh para ahli dan modul pembelajaran fisika berbasis PBL guru fisika. Selanjutnya dilakukan uji coba pada pada pokok bahasan Gelombang terbatas kepada 10 peserta didik SMA kelas Bunyi. XII dan revisi berdasarkan uji coba terbatas dan diperoleh hasil akhir modul

\section{METODE PENELITIAN}

Pengembangan (Research and Development) yaitu jenis penelitian yang mengembangkan suatu produk baru atau menyempurnakan produk yang telah ada sebelumnya. Penelitian pengembangan ini mengacu pada model 4D dengan modifikasi. Model 4D merupakan singkatan dari define, design, development and dissemination yang dikembangkan oleh Thiagarajan, Semmel \& Semmel (1974). Dalam penelitian ini dibatasi sampai tahap develop pada uji coba terbatas. Pada tahap define dilakukan analisis kebutuhan, analisis materi yang dianggap sulit melalui angket dan analisis silabus berdasarkan kurikulum 2013. Pada tahap design dilakukan perumusan RPP sekaligus divalidasi oleh pakar, selanjutnya pemilihan bahan ajar yaitu modul, pemilihan format sehingga dihasilkan Prototype modul, selanjutnya membuat desain awal modul sekaligus membuat angket validasi kelayakan modul dari segi materi, media, bahasa, dan respon siswa. pembelajaran fisika berbasis PBL.

\section{HASIL DAN PEMBAHASAN}

Penelitian pengembangan ini menghasilkan modul pembelajaran fisika berbasis Problem Based Learning (PBL). PBL adalah suatu model pembelajaran, yang mana siswa sejak awal dihadapkan pada suatu masalah, kemudian diikuti oleh proses pencarian informasi yang bersifat Student Centered (Arends, 2007). Pada modul permasalahan terletak pada kolom Let's Think dimana siswa diberikan permasalahan kontekstual sebelum materi, untuk memecahkan permasalahan tersebut siswa dituntut mencari informasi sendiri melalui kegiatan pada kolom Let's Find Out, namun sebelum siswa melakukan kegiatan tersebut siswa dihadapkan pada kolom Procedure. Modul yang dikembangkan mempunyai dua fungsi yaitu sebagai alat bantu belajar mandiri siswa dirumah dan dapat digunakan guru sebagai alat bantu atau tambahan untuk mengajar di kelas. Hal ini sesuai dengan 
tujuan modul yaitu memungkinkan peserta didik belajar mandiri sesuai kemampuan dan minatnya (Depdiknas,2008).

Pada tahap define dilakukan analisis kebutuhan dengan menyebarkan angket kebutuhan kepada siswa SMA N 2 Malang sejumlah 36 orang dari dua kelas yakni kelas XII MIPA 2 dan XII MIPA 3. Dari penyebaran angket tersebut diperoleh kesimpulan bawasannya siswa belum bisa memecahkan masalah dengan buku yang ada, masih belum bisa belajar mandiri sehingga masih perlu adanya bimbingan dari guru, siswa membutuhkan modul yang dapat mengasah kemampuan memecahkan masalah dunia nyata, dan bagi siswa materi gelombang bunyi dianggap sulit untuk dipahami. Pada langkah analisis ini pemilihan materi berdasarkan penyebaran angket keterbutuhan yang menyatakan bahwa 28 siswa dari 36 siswa berpendapat bahwa materi gelombang bunyi tergolong materi yang sulit dipahami. Sehingga pada penelitian ini akan mengembangkan modul pembelajaran fisika pada materi Gelombang Bunyi yang terdiri dari beberapa sub bab diantaranya pengertian gelombang bunyi, sifat-sifat gelombang buyi, cepat rambat bunyi, sumber bunyi, efek doppler, energi gelombang bunyi, dan aplikasi gelombang buyi. Selanjutnya untuk analisis silabus disesuaikan dengan silabus kurikulum 2013. Peneliti melakukan analisis kompetensi inti dan kompetensi dasar untuk menentukan konsep materi yang akan dijadikan modul. Hasilnya ditetapkan menggunakan KD 1.1, $\mathrm{KD} 2.2$, KD 3.1 dan $\mathrm{KD} 4.1$ yang mencakup materi Gelombang Bunyi.

Pada tahap design dilakukan pengembangkan RPP untuk kelas XII semester 1 pada pokok bahasan gelombang bunyi yang kemudian divalidasi oleh pakar. Dalam lembar validasi RPP, selain memuat tentang penilaian kelayakan RPP pembelajaran yang diisi oleh validator, juga disertakan lembar saran yang bertujuan untuk memperbaiki RPP. Setelah validasi pada RPP oleh validator, dilakukan revisi pada beberapa bagian RPP oleh peneliti atas dasar saran validator. Setelah revisi pada bagian RPP dilakukan, maka hasil produk RPP yang siap untuk dijadikan dasar membuat modul.Berdasarkan hasil validasi RPP oleh para validator diperoleh grafik seperti pada Gambar 1 berikut

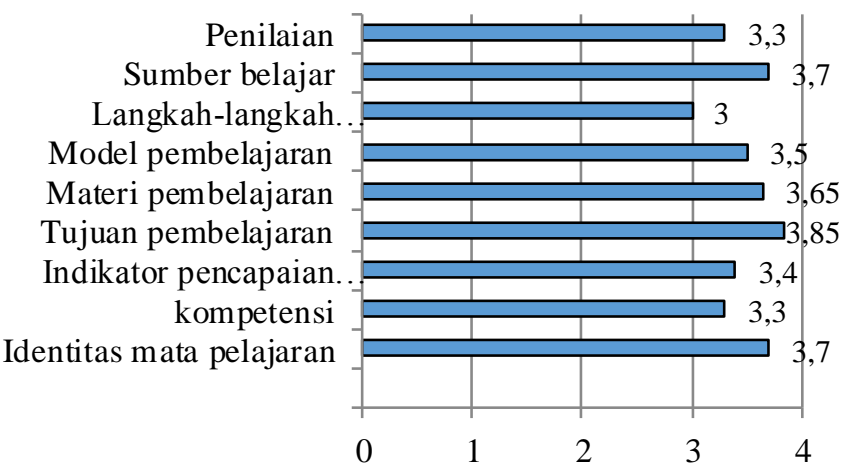

Gambar 1. Grafik Hasil Validasi RPP 
Berdasarkan Gambar 1., pada kesesuaian modul dengan kebutuhan langkah-langkah pembelajaran mendapat sehingga modul tersebut layak dan cocok nilai rata-rata terendah yaitu 3 dengan digunakan dalam pembelajaran kriteria cukup layak, dikarenakan kurang (Depdiknas, 2008). Dalam langkah ini memenuhi standar yang benar sehingga peneliti memberikan instrumen penelitian perlu direvisi sesuai dengan saran dari kepada validator. kemudian para validator validator yaitu membagi kegiatan guru dan memberikan penilaian terhadap modul siswa secara terperinci. Selain itu pada yang telah dibuat oleh peneliti. Dalam tahap design juga diperoleh draft awal yang penelitian ini, validator yang dipilih akan digunakan untuk membuat modul. berkompeten dan mengerti dalam Hal ini sesuai dengan tujuan penyusunan penyusunan modul pembelajaran fisika draft yaitu menyediakan draft suatu modul berbasis PBL dan mampu memberikan sesuai dengan kompetensi atau sub masukan atau saran untuk kompetensi yang telah ditetapkan menyempurnakan modul pembelajaran (Depdiknas, 2008) draft awal modul dapat yang telah disusun. Saran-saran dari dilihat pada Gambar 2., berikut

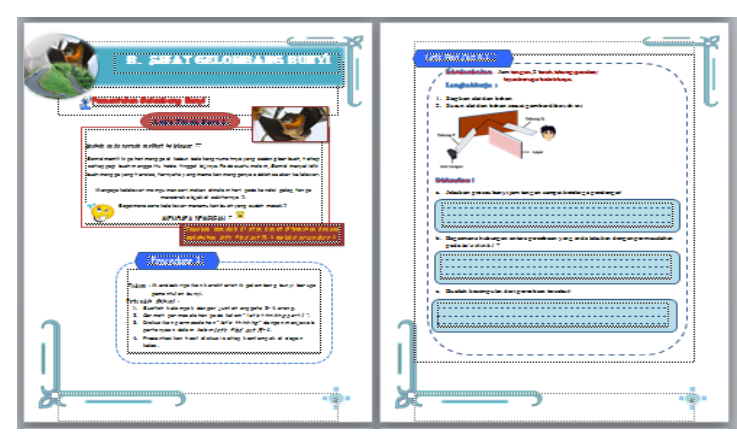

Gambar 2. Draft Modul

Pada tahap develop bertujuan untuk menghasilkan modul pembelajaran fisika berbasis Problem Based Learning dilakukan dengan tahap validasi yang terdiri dari validasi materi, validasi media dan guru fisika SMA. Hal ini sesuai dengan tujuan validasi modul yaitu untuk memperoleh pengakuan atau pengesahan validator tersebut dijadikan bahan untuk menyempurnakan modul yang telah dibuat. Berdasarkan hasil validasi materi oleh para validator diperoleh grafik seperti Gambar 3.

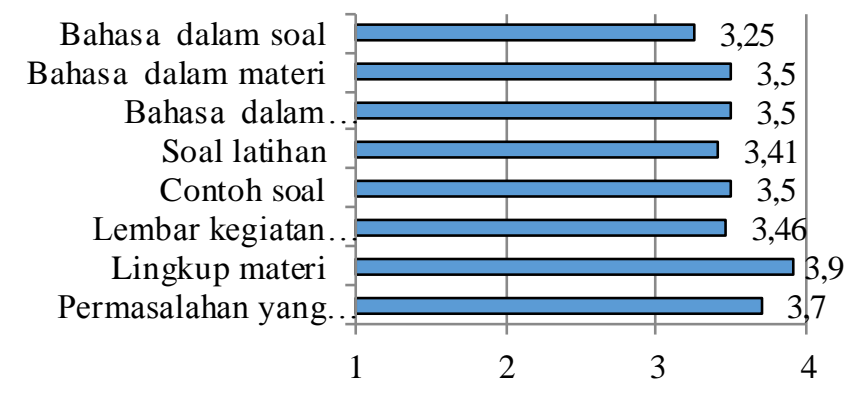

\section{Gambar 3. Grafik Hasil Validasi Materi}

Berdasarkan Gambar 3 komponen soal latihan diperoleh nilai rata-rata terendah yaitu 3,41 dengan kriteria layak namun perlu perbaikan berupa menambah opsi pilihan ganda sampai opsi E. 
Berdasarkan hasil validasi media oleh para validator diperoleh grafik seperti Gambar 4.

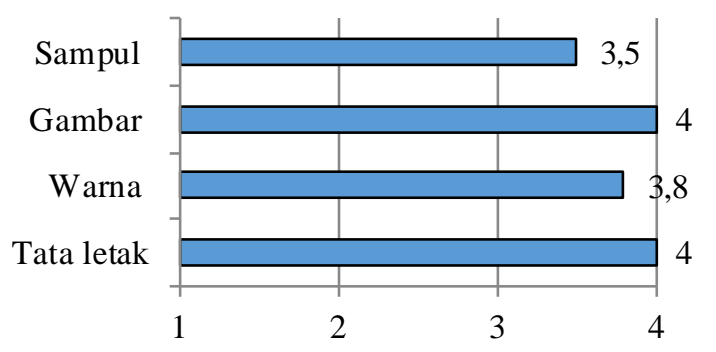

Gambar 4. Grafik Hasil Validasi Media

Berdasarkan Gambar 4 pada komponen sampul mendapat nilai rata-rata terendah dibanding komponen lainya yaitu 3,5 dengan kriteria layak, namun perlu adanya perubahan pada sampul sesuai dengan saran dari validator diantaranya tatanan yang kurang proposional, huruf dan warna yang terlalu banyak sehingga perlu adanya direvisi.

Berdasarkan hasil validasi modul pembelajaran berbasis PBL oleh 2 dosen fisika dan 2 guru fisika diperoleh grafik seperti Gambar 5., sebagai berikut.

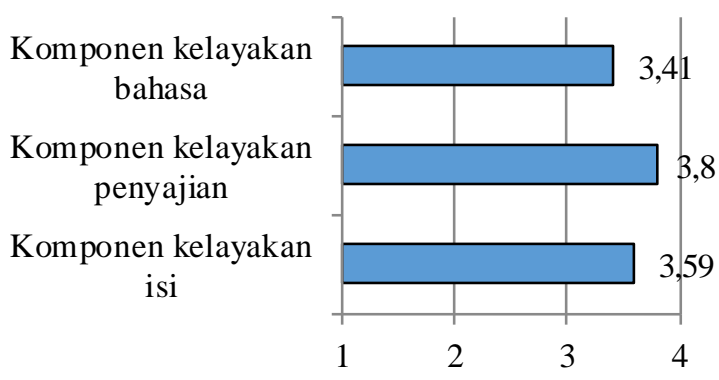

Gambar 5. Hasil Validasi Modul Pembelajaran Fisika berbasis PBL
Setelah itu dilakukan uji coba terbatas kepada siswa SMA kelas XII. Uji coba terbatas sangat penting dilakukan karena tujuan uji coba yaitu untuk mengetahui kemampuan dan kemudahan peserta didik dalam memahami dan menggunakan modul (Depdiknas, 2008). Pada tahap uji coba terbatas dilakukan kepada 10 siswa SMA kelas XII yang dipilih secara heterogen terdiri dari tingkat siswa dengan kemapuan tinggi, sedang dan rendah yang telah disarankan oleh guru mata pelajaran fisika yang mengajar dikelas tersebut. Berdasarkan hasil uji coba terbatas kepada sepuluh siswa kelas XII SMA diperoleh grafik seperti Gambar 6., sebagai berikut.

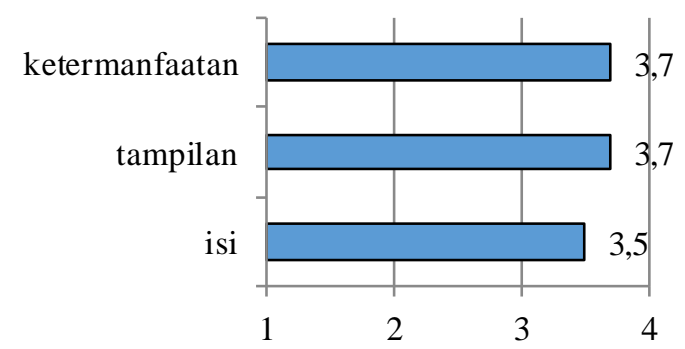

\section{Gambar 6. Grafik Hasil Uji Coba Terbatas Kepada Siswa}

Berdasarkan Gambar 6 komponen isi mendapat nilai rata-rata terendah dibanding komponen yang lain yaitu 3,5 dengan kriteria sesuai namun perlu adanya perbaikan seperti peta konsep, contoh soal, dan soal latihan yang perlu ditambah.

Hasil penelitian dan pengembangan modul pembelajaran fisika berbasis $\mathrm{PBL}$ 
tidak semua komponen mendapatkan nilai yang sangat baik, hal ini berarti terdapat kelebihan dan kekurangan dari modul ini. Kelebihan dari modul pembelajaran fisika berbasis PBL berdasarkan hasil validasi dan uji coba terbatas adalah : (1) memiliki desain yang menarik dengan perolehan skor rata-rata 4 pada komponen gambar dan tata letak, (2) dapat membantu siswa belajar secara mandiri , (3) membantu siswa melakukan kegiatan ilmiah karena terdapat banyak eksperimen di dalam modul hal ini sesuai dengan hasil uji coba terbatas yang mendapatkan skor rata-rata sebesar 3,7 pada ketertarikan siswa terhadap kegiatan ilmiah yang berada pada modul, (4) dapat membantu siswa dalam penguasaan konsep karena soal-soal yang terdapat dalam modul mencakup ranah kognitif C1-C6. Hal ini sesuai dengan 6 kategori proses kognitif dalam perbaikan taksonomi Bloom oleh Anderson untuk menguasai konsep yaitu: mengingat (remember), memahami (understand), menerapkan (apply), menganalisis (analize), mengevaluasi (evaluate), membuat (create) (Sagala, 2008).

\section{Kekurangan dari modul} pembelajaran fisika berbasis PBL adalah : (1) hanya tercantum 1 materi saja, (2) kurang praktis karena tidak dibuat bolakbalik, (3) contoh soal masih sedikit.
Selain kelebihan dan kekurangan pada modul pembelajaran fisika berbasis PBL, selama melakukan penelitian juga mengalami beberapa kendala dan hambatan antara lain : (1) pengembangan modul ini diperuntukan kelas XII sehingga waktu dalam penelitan kurang maksimal, (2) rencana awal pada penelitian akan menggunakan lebih dari 2 validator guru fisika SMA dikarenakan keterbatasan waktu dan biaya, sehingga hanya menggunakan 2 guru fisika SMA.

\section{SIMPULAN}

Berdasarkan penelitian pengembangan modul dapat disimpulakan bahwa telah dihasilkan Modul pembelajaran fisika berbasis Problem Based Learning pada materi Gelombang Bunyi untuk peserta didik SMA kelas XII, yang dikembangkan menggunakan model 4-D (Define, Design, Develop, dan Dissiminate) dimodifikasi yang dibatasi sampai dengan tahap Develop dan uji coba terbatas. Komponen yang ada dalam modul meliputi : cover, lembar let's think, lembar let's find out, pemaparan materi, contoh soal, soal latihan, rangkuman, lembar proyek, uji kompetensi, remidial, pengayaan dan soal latihan mendalam.

Modul pembelajaran fisika berbasis Problem Based Learning pada materi Gelombang Bunyi kelas XII SMA 
dikategorikan layak digunakan sebagai bahan ajar. Hal ini berdasarkan validasi yang menyatakan bawasanya kelayakan isi diperoleh skor sebesar 3,59 dengan kritria layak, kelayakan penyajian diperoleh skor sebesar 3,9 dengan kriteria layak, dan kelayakan bahasa yang digunakan diproleh skor sebesar 3,41 dengan kriteria layak. Hasil uji coba pada peserta didik skala terbatas diperoleh skor sebesar 3,5 untuk isi modul, skor sebesar 3,7 untuk tampilan modul, dan skor sebesar 3,7 untuk ketermanfaatan dengan kategori layak.

Pemanfaatan modul ini dalam proses pembelajaran sebaiknya sesuai dengan petunjuk penggunaan modul agar mendapat hasil yang optimal. Penelitian ini sampai validasi dan uji coba terbatas sehingga perlu dilakukan pengembangan lebih lanjut. Selain itu, dalam penelitian ini subjek uji coba terbatas hanya diwakili oleh sepuluh peserta didik sehingga untuk pengembangan produk lebih lanjut perlu uji coba dengan skala lebih luas. Penelitian pengembangan modul lebih lanjut dapat dilakukan dengan menguji efektivitas modul dalam meningkatkan pemahaman konsep peserta didik. Tahap diseminasi hasil pengembangan dapat dilakukan dengan menyebarkan modul pembelajaran fisika berbasis PBL kepada guru fisika atau MGMPS

\section{DAFTAR RUJUKAN}

Arywiantari, D., Agung, A.A.G., Tastra, I.D.K. (2015). Pengembangan Multimedia Interaktif Model 4D Pada Pembelajaran IPA di SMP Negeri 3 Singaraja. E-journal Edutech Universitas Pendidikan Ganesa.

Chiang \& Lee. (2016). The Effect of Project-Based Learning on Learning Motivation and Problem-Solving Ability of Vocational High School Students. International Journal of Information and Education Technology

Depdiknas. (2007). Kajian Kebijakan Kurikulum SMK. Jakarta: Dinas Pendidikan Nasional.

Depdiknas. (2008). Penulisan Modul. Jakarta : Depdiknas

Harsono. (2005). Pengantar Problem Based Learning Edisi Kedua. Yogyakarta: MEDIKA Fakultas kedokteran UGM.

Mulyasa, E. (2009). Kurikulum Tingkat Satuan Pendidikan. Bandung: remaja rosdakarya.

Muslich, M. (2010). Pembelajaran Berbasis Kompetensi dan Kontekstual. Jakarta: Bumi Akara Mutia, B., \& Serevina, V.A.S. (2014). Pengembangan Perangkat Pembelajaran Fisika Sma Berbasis 
Problem Based Learning Sebagai Implementasi Scientific Approach Dan Penilaian Authentic. Jurnal Nasional .

Nugraha, D.A., Binadja, A., \& Supartono. (2013). Pengembangan Bahan Ajar Reaksi Redoks Bervisi Sets, Berorientasi Konstruktivistik. Jounal of Innovative Science Education.

Sagala, S. (2008). Konsep Dan Makna Pembelajaran. Bandung: CV Alfabeta

Sadgolu, G.P. (2013). 9th grade student s'mental models about the sound concept. International Journal of Education Research And Tecnology.

Sulistyarini, E. (2015). Pengembangan Bahan Ajar Fisika Sma Materi Gelombang Bunyi Berbasis Interactive. Skripsi tidak diterbitkan. Semarang: Universitas Negeri Semarang .

Ukoh., E, E. (2012). Determining the effect of problem-based learning instructional strategy on nce preservice teachers' achievement in physics and acquisition of science process skills. European Scientific Journal.

Wulandari, W.D. (2015). Pengembangan modul Fisika berbasis Guide Inquiri pada materi suhu dan kalor untuk meningkatkan keterampilan proses sains siswa SMA kelas X. Skripsi tidak diterbitkan. Malang: MIPA Universitas Negeri Malang

Wittmann, C.M. (2003). Understanding and affecting student reasoning about sound waves. Intenational Journal Of Science Education. 